\title{
Birth, recruitment and juvenile growth in the intraovarian brooding sea cucumber Leptosynapta clarki
}

\author{
Mary A. Sewell ${ }^{* * * *}$ \\ Bamfield Marine Station, Bamfield, British Columbia, Canada V0R 1B0 \\ and \\ Department of Zoology, University of Alberta, Edmonton, Alberta, Canada T6G 2E9
}

\begin{abstract}
Leptosynapta clarki is a brooding apodid sea cucumber found on the intertidal mudflats on the west coast of Vancouver Island, Canada. In the early spring (April/May), juveniles burrow into the sediment after release from the mother by rupturing of the body wall. There is potential for dispersal after release, but the juveniles form a distinct recruitment pulse in the adult habitat. Monitoring of the population in the field shows rapid growth from a mean size of 1 to $2 \mathrm{~mm}$ at release to a maximum of $16 \mathrm{~mm}$ in August. After August, the juveniles become pigmented and are indistinguishable from the adult population. Growth estimates from the laboratory show that during the reproductive season following their birth (November to December), the sea cucumbers are a maximum of $35.5 \mathrm{~mm}$ in length (mean $18.7 \mathrm{~mm}$ ), and are reproductively active as males. At the age of $1 \mathrm{yr}$ the mean size is $21.1 \mathrm{~mm}$ with a maximum length of $44 \mathrm{~mm}$. This study provides the first data on recruitment in an apodid sea cucumber and provides detailed information on the growth rates and early life history of $L$. clarki.
\end{abstract}

KEY WORDS: Apodid $\cdot$ Birth $\cdot$ Brooding $\cdot$ Growth $\cdot$ Recruitment $\cdot$ Holothurian $\cdot$ Leptosynapta clarki

\section{INTRODUCTION}

The majority of sea cucumbers are broadcast spawners, with external fertilization and planktonic development. However, over 40 species of holothurians brood their young under the sole, in the tentacles, in brood pouches or pockets, or internally in the coelom or ovary (Smiley et al. 1991). Although there is some information on life history characters and embryonic development in brooding species (Smiley et al. 1991), there is limited information on the events occurring immediately after juvenile release. For internal brooders, only Engstrom (1980) has observed juveniles in the benthic habitat soon after release, and gives information on early growth.

Leptosynapta clarki is an apodid holothurian found on the Pacific coast of North America, from Central

\footnotetext{
- Present address: Dept of Biological Sciences, Simon Fraser University, Burnaby, British Columbia, Canada V5A 1 S6

-Address for correspondence: Canadian Wildlife Service, PO Box 340, Delta, British Columbia, Canada V4K 3 Y3
}

California northwards into British Columbia as far as the Queen Charlotte Islands (McEuen 1987, Sewell, Thandar \& Chia unpubl.). It is an intraovarian brooder, the fertilized eggs developing rapidly to the pentactula stage (1 to $2 \mathrm{wk}$, Sewell \& Chia 1994) and remain in the ovary for 5 to 6 mo (Everingham 1961, Sewell \& Chia 1994). Although the embryology of brooding in $L$. clarki has been described (Everingham 1961), the subsequent fate of the juveniles after release has not been determined. In this study a recruitment pulse of newly released juveniles was observed on the mudflats in the late spring (April/ May). Growth of the juveniles could be followed in the field until the end of the summer (August), when rapid growth made them indistinguishable from sea cucumbers of age $>1$ yr. Hereafter, laboratory growth experiments allowed growth to be measured until the sea cucumbers were 1 yr old. This paper provides the first detailed field study of postrelease and juvenile growth of an apodid sea cucumber, and represents a first step in our understanding of the early life history in $L$. clarki after release of pentactulae from the ovary. 


\section{MATERIALS AND METHODS}

Measurement of size. Measurements of length (in $\mathrm{mm}$ ) were made after relaxation of the sea cucumbers in $2.5 \% \mathrm{MgCl}_{2}$ in sea water (w/v) in a $90 \mathrm{~mm}$ petri dish. During relaxation the sea cucumbers would often retract or withdraw the tentacles. To standardise this measurement, length was measured from the anterior end of the calcareous ring to the posterior while in the $\mathrm{MgCl}_{2}$ relaxation solution. Specimens $<20 \mathrm{~mm}$ were measured on a dissecting microscope using an eyepiece graticule calibrated against a stage micrometer. Larger specimens were gently held straight with tweezers and length measured to the nearest mm with reference to a small plastic ruler under the petri dish.

After measurement of length, the sea cucumber was placed on a tissue to remove external water, and weighed on a fine-scale balance to the nearest $\mathrm{mg}$ (total weight). There are some errors in this measure as the weight includes sediment and/or water in the alimentary canal. However, sea cucumbers left in sea water for removal of sediment tended to autotomize the posterior end, which led to greater inaccuracies in measurement of size.

Size of pentactulae prior to release. Female Leptosynapta clarki were collected from Barge Bay, Grappler Inlet, Bamfield, British Columbia (Site 1: $48^{\circ} 49^{\prime} 57^{\prime \prime} \mathrm{N}, 125^{\circ} 06^{\prime} 45^{\prime \prime} \mathrm{W}$; see Sewell \& Chia 1994; Fig. 1) on 13 April $1990(n=6)$ and during late March and early April 1991 (23 to 30 March and 8 April 1991, $\mathrm{n}=29$ ). Females were relaxed in $2.5 \% \mathrm{MgCl}_{2}$ and the gonad dissected into a petri dish. Pentactulae were removed from the gonad tubules by gentle teasing with fine needles and size was measured as described above. In 1990 the pentactulae from 4 females were set up in subcontainers 1 to 6 as a pilot study for the growth experiments $(n=38$ pentactulae; see details below). Pentactulae from the remaining 2 females were used in pilot studies to test for recovery after relaxation in the $\mathrm{MgCl}_{2}$ solution.

Recruitment and growth in the field. Recruitment in Leptosynapta clarki was monitored in sediment cores from the mid-intertidal mudflat in Barge Bay (Site 1). Random samples were taken using a perspex core (cross-sectional area $=785.4 \mathrm{~mm}^{2}$ ) to a depth of ca $10 \mathrm{~cm}$ ( $\mathrm{n}=10$ cores; total area sampled $=0.078 \mathrm{~m}^{2}$ ). Core samples were combined in buckets and returned to the laboratory. Pilot studies found no sea cucumbers below $10 \mathrm{~cm}$ because of the shallow anoxic layer (unpubl. data). Samples were taken every 2 mo from May 1990 until August 1991

In the laboratory the sediment was sieved through a $2 \mathrm{~mm}$ or $0.85 \mathrm{~mm}$ sieve to remove adults, and the remaining fraction sieved through a $0.25 \mathrm{~mm}$ sieve to remove juveniles. Specimens were kept in sea water for a maximum of $4 \mathrm{~h}$ before measurement (length and weight). From May until August 1990, only juvenile sea cucumbers were measured. Juveniles $<1$ yr old could be distinguished from older individuals as they were unpigmented. However, after August there was no clear distinction between age classes and measurements were made on all sea cucumbers in the sample. Weight of newly released juveniles in May 1991 was determined by regression (length vs log weight for individuals 0 to $10 \mathrm{~mm}$ in length from the 15 July 1991 sample: $\log$ weight $=0.114$ (length) $-0.0197 ; r^{2}=0.793$, $\mathrm{n}=33$ ).

Laboratory growth of juveniles. Growth experiments were conducted in 2 flat plastic trays $(417 \times 356$ $\times 115 \mathrm{~mm}, \mathrm{~L} \times \mathrm{W} \times \mathrm{D}$ ), subdivided into 6 approximately equal divisions by wooden partitions sealed at the edges with silicon sealant (i.e. each subcontainer ca $125 \times 155 \mathrm{~mm}$ ). Each subcontainer was provided with air from an airstone glued to the base. 'Airstones' were constructed from a $75 \mathrm{~mm}$ length of $1 \mathrm{~mm}$ borosilicate disposable pipette with 3 small holes on the upper surface. The pipettes were covered with $64 \mu \mathrm{m}$ Nitex screening which provided slow, diffuse aeration throughout each subcontainer.

Each container was filled to a depth of 70 to $100 \mathrm{~mm}$ with sediment collected from Barge Bay. This sediment was sieved through a $0.85 \mathrm{~mm}$ sieve to remove any sea cucumbers before placing in the experiment. However, when mud was added to the container to replace sediment lost as a result of aeration, additional juvenile sea cucumbers were sometimes introduced. These specimens could be identified because of their small size and were ignored in the size-frequency analyses. The containers were immersed in a $1.7 \times 0.72 \times 0.22 \mathrm{~m}$ sea water tray with flow-through sea water. Water temperature throughout the experiment ranged from ca 8 to $11^{\circ} \mathrm{C}$.

Juvenile sea cucumbers used in the growth experiment were obtained by dissection of the mother (subcontainers 1 to 6 ) as described above, or from field collections (subcontainers 7 to 12). Sediment was collected from Barge Bay on 14 May 1990, sieved through a $2 \mathrm{~mm}$ sieve to remove the adults, and then the remaining fraction spread in a shallow layer in trays and allowed to settle. Under bright light, reflection of the calcareous ring made juvenile Leptosynapta clarki visible on, or near, the surface in shallow burrows Juveniles were removed from the trays using a wide bore pipette. Length was measured after relaxation in the $\mathrm{MgCl}_{2}$ solution and the sea cucumbers placed in the sediment of the subcontainers.

Repeated measurements of size were made at 2 mo intervals from May 1990 until May 1991. At such times sea cucumbers were removed from the sediment in each subcontainer using a $0.85 \mathrm{~mm}$ sieve, measured 
and returned to their respective subcontainers. The data presented are the pooled results of the 2 containers from 24 July 1990 until 12 May 1991. Although the experiment began in May 1990, the early results could not be used because of contamination of subcontainers 1 to 6 by additional juvenile sea cucumbers. In subsequent additions of sediment, special care was made to remove all sea cucumbers. The initial number of sea cucumbers in subcontainers 1 to 12 on 24 July 1990 was 245

\section{RESULTS}

\section{Field collections}

Pentactulae removed from the ovarian tubules in April 1990 ranged from 0.46 to $6.67 \mathrm{~mm}$ (mean $\pm \mathrm{SD}=$ $2.00 \pm 1.04 \mathrm{~mm}, \mathrm{n}=100$ ). Pentactulae in most ovaries were less than $4 \mathrm{~mm}$ in length, with a modal size of 1 to $2 \mathrm{~mm}$ (Fig. 1). A similar size-frequency distribution was observed in late March 1991 (Fig. 2), although the sample was taken earlier and the mean length was
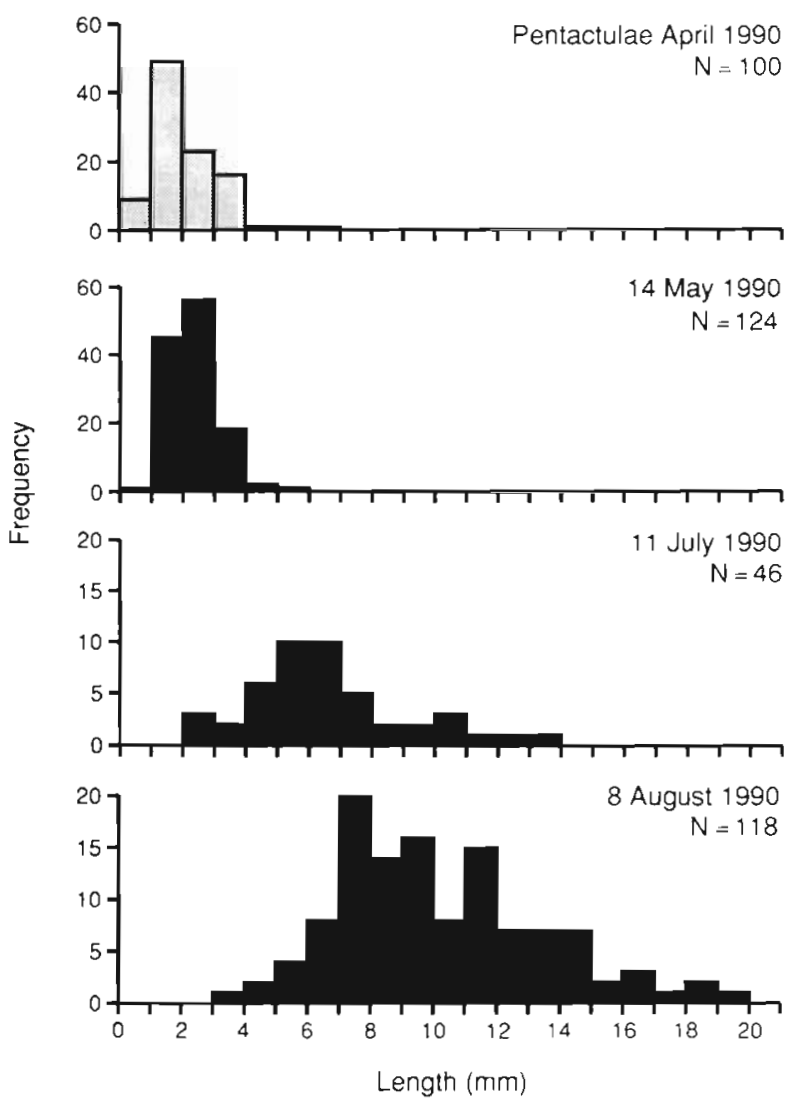

Fig. 1 Leptosynapta clarki. Size-frequency distributions of pentactulae prior to release (grey bars) and during growth in sediment (black bars) in 1990

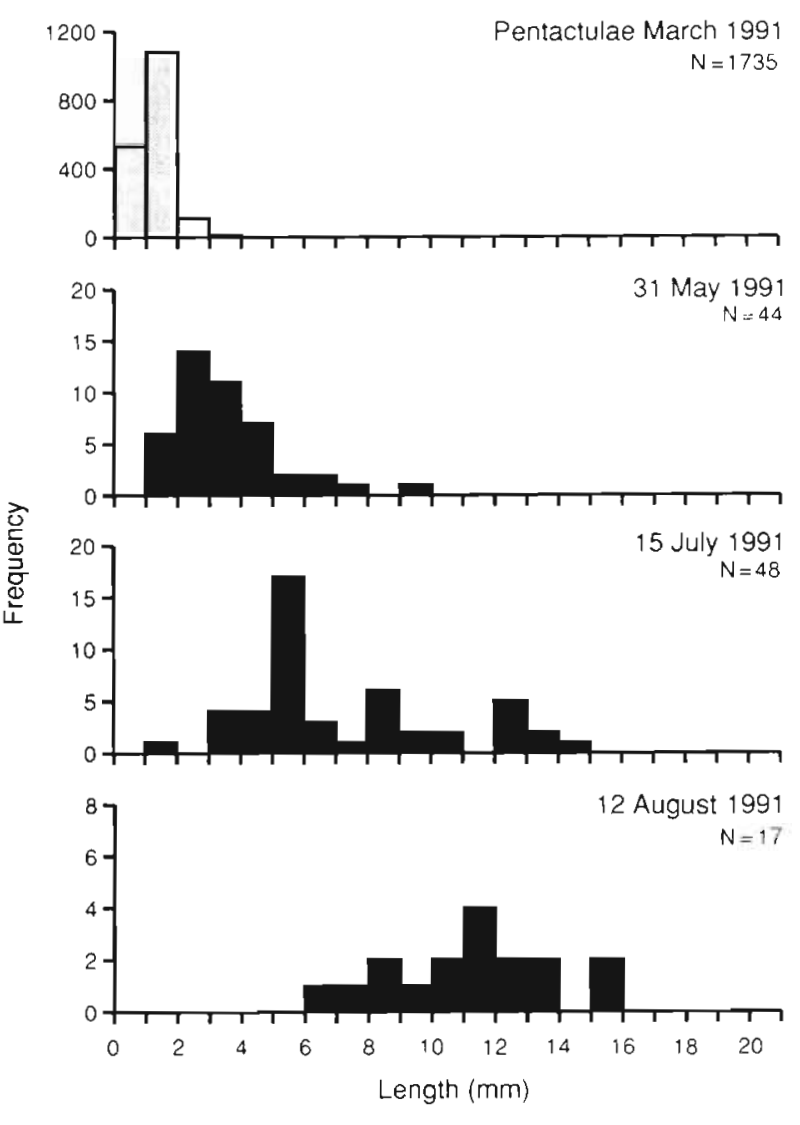

Fig. 2. Leptosynapta clarki. Size-frequency distributions of pentactulae prior to release (grey bars) and during growth in sediment (black bars) in 1991

lower at $1.24 \mathrm{~mm}(\mathrm{SD}=0.463 \mathrm{~mm}, \mathrm{n}=1735$, range $=$ 0.32 to $3.4 \mathrm{~mm}$ ).

Release of the pentactulae was never observed in nature, although in the laboratory normal handling of the female sea cucumbers during April and May would often result in the release of juveniles. Prior to release of the pentactulae from the coelom a break point occurs in the area between the brooding portion of the ovary and the basal region of renewed growth (Sewell \& Chia 1994). The posterior distal part of the ovarian tubule then becomes loose in the coelom (Sewell \& Chia 1994). During handling, the end of this tubule would often protrude out the body wall in the region of the anus. It is uncertain whether the tubule passes through the anus itself or through the body wall adjacent to the anus. Movement of the female resulted in the breaking of the thin ovarian wall and release of the juveniles. Female sea cucumbers were also very prone to autotomize during this period. Autotomy of the posterior end of the individual similarly exposed the tubules to the exterior and resulted in juvenile release. If sediment was provided, the juveniles rapidly dug shallow burrows. 
After release from the mother at a length of 1 to $2 \mathrm{~mm}$ (Figs. 1 \& 2), rapid growth was observed in the field to a maximum of $5.00 \mathrm{~mm}$ in mid-May 1990 (Fig. 1) and $9.13 \mathrm{~mm}$ in late May 1991 (Fig. 2). By July, the modal length was 5 to $6 \mathrm{~mm}$, with a maximum of $13.78 \mathrm{~mm}$ in 1990 (Fig. 1), and $14.77 \mathrm{~mm}$ in 1991 (Fig. 2). There is considerable variability in growth during the late summer, so that by August the juveniles are generally 6 to $16 \mathrm{~mm}$ in length (Figs. 1 \& 2).

Release of juveniles into the sediment could be observed as a recruitment pulse into the adult population in Barge Bay (Fig. 3). The juveniles released in April/ May 1990, were still visible as a distinct cohort in both length and weight in August (Fig. 3). By October, the juvenile cohort was indistinguishable from the adult population in length (Fig. 3A), and remained so throughout the autumn and winter. There were, however, a number of indistinct modes in weight (Fig. 3B). Newly released juveniles are clearly visible as a recruitment pulse in May 1991 (Fig. 3). This new cohort showed rapid growth through the summer (Fig 2), and was still visible as a distinct cohort in both length and weight in August 1991 (Fig. 3).

The density of Leptosynapta clarki in the Barge Bay population was fairly constant throughout the period of sampling (mean $\pm \mathrm{SD}: 168.8 \pm 34.6 \mathrm{~m}^{-2}, \mathrm{n}=8$ ). No consistent changes in density were noted throughout the year as both the lowest density $\left(124.8 \mathrm{~m}^{-2}\right)$ and the highest density were found in August $\left(244.5 \mathrm{~m}^{-2}\right)$. Density estimates of L. clarki in Barge Bay may, however, be affected by the patchy distribution of juveniles (pers. obs.)

The largest individual observed at this site was $82 \mathrm{~mm}$ in length and $1060 \mathrm{mg}$ in weight. Specimens of Leptosynapta clarki do, however, attain larger sizes at other sites in Grappler Inlet. The largest specimen found at Bamfield had a length of $113 \mathrm{~mm}$ and weighed $1291 \mathrm{mg}$ (Sewell 1994)

\section{Laboratory growth of juveniles}

Growth of Leptosynapta clarki in the laboratory was similar to that observed in the field collections (Fig. 4 , Table 1). However, in the laboratory growth could be monitored after August when the Year 1 juveniles were

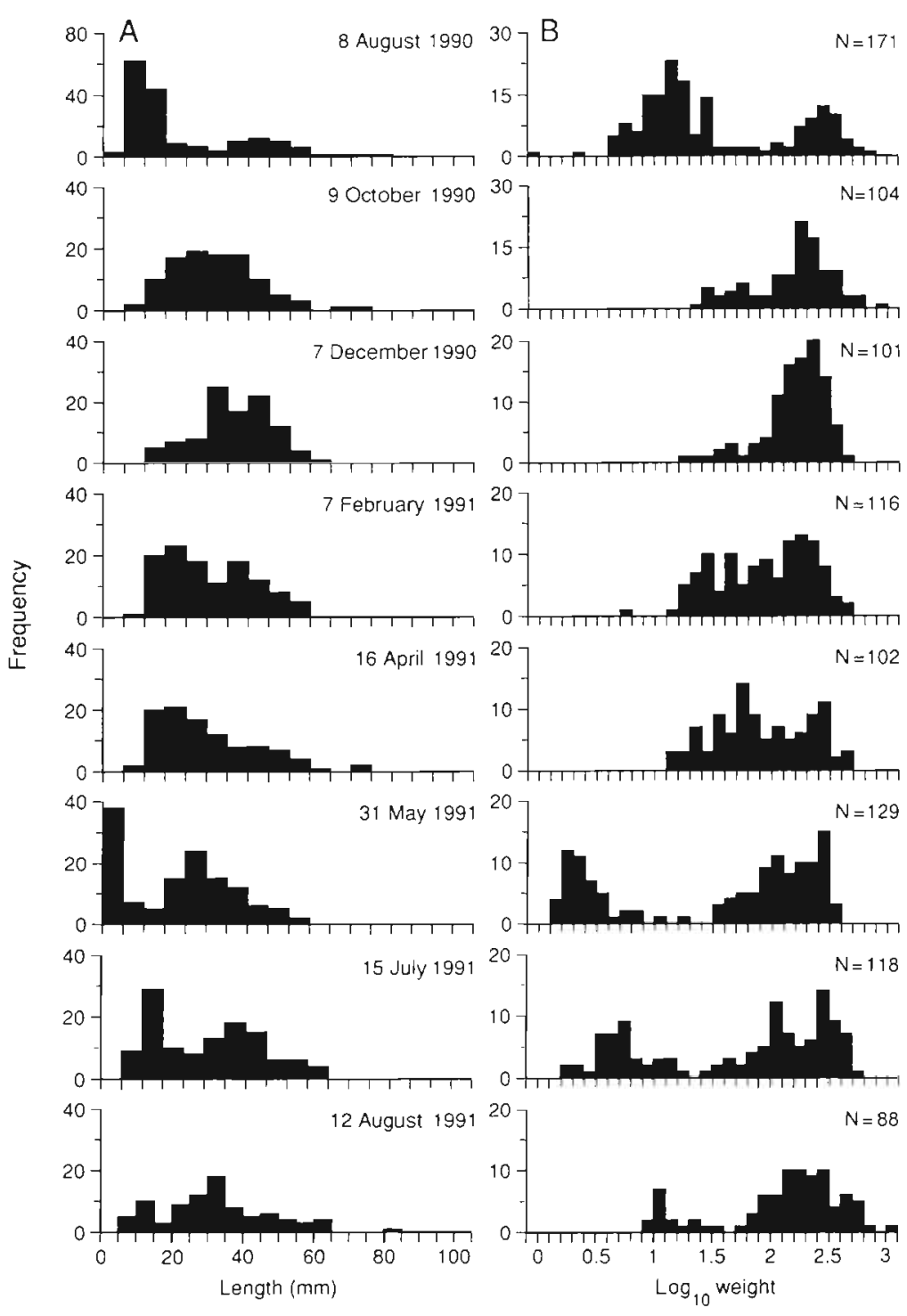

Fig. 3. Leptosynapta clarki. Size-frequency distributions in Barge Bay from August 1990 to August 1991. (A) Size measured as length (mm). (B) Size measured as $\log _{10}$ weight (original data in $\mathrm{mg}$ ). Dates of collection are shown in (A); number of sea cucumbers in sample in (B)

indistinguishable from adults in field samples. In late July 1990, juveniles in the laboratory showed a mode at 6 to $7 \mathrm{~mm}$ (Fig. 4), which was similar to that in the field (Fig. 1), although with a larger variability. Juveniles continued to grow rapidly until they reached a maximum of $30 \mathrm{~mm}$ by September (Fig. 4), and a mean weight of $23 \mathrm{mg}$ (Table 1). No laboratory measurements were made in August to compare with the field collections, but the mean for the August field sample (mean $\pm \mathrm{SD}$ : $10.22 \pm 3.20 \mathrm{~mm}, \mathrm{n}=118$ ) is intermediate between the laboratory means for July and September (Table 1). Based on the 1990 field collections, it appears that juvenile growth estimates from the laboratory are in the same range as those found in natural populations. 

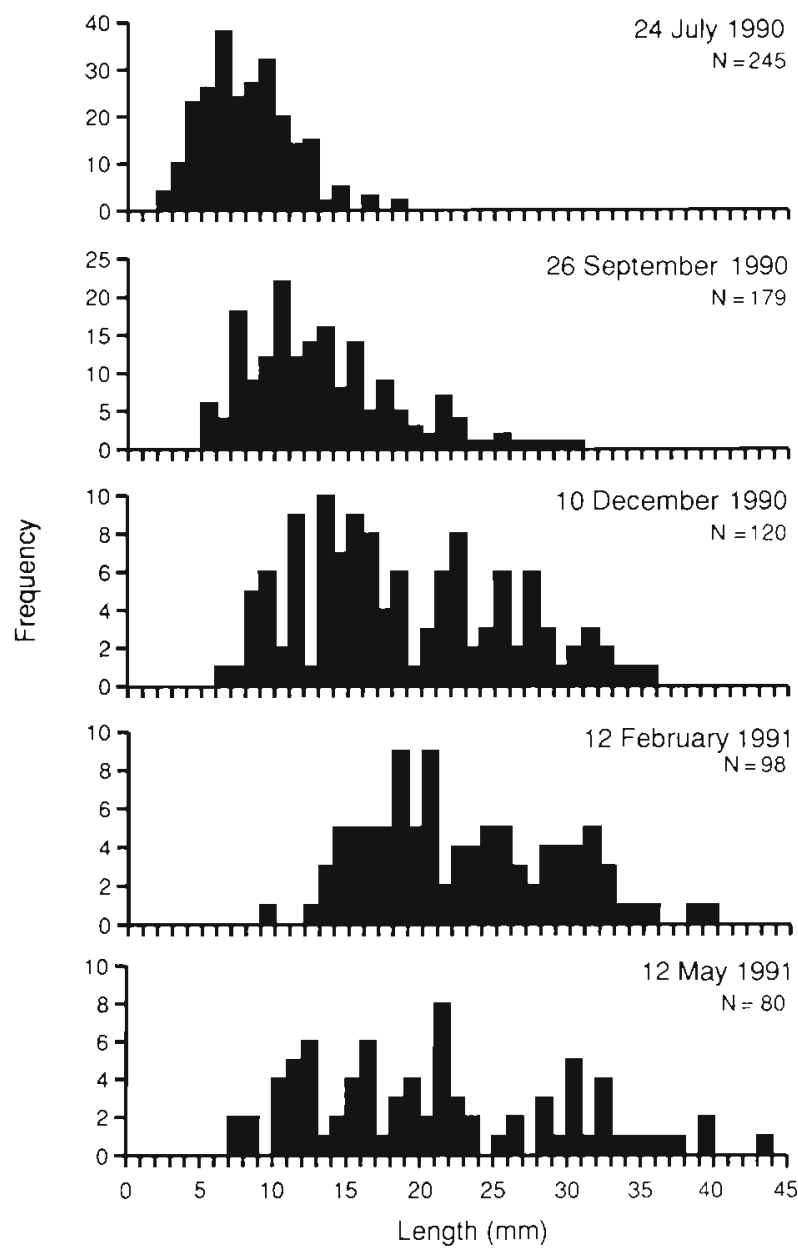

Fig. 4. Leptosynapta clarki. Laboratory growth until an age of approximately 1 yr. Size-frequency distributions in length $(\mathrm{mm})$ are pooled results from subcontainers 1 to 12

At the time of spawning of Leptosynapta clarki in November/December the maximum length of young of the year was $35.5 \mathrm{~mm}$ (Fig. 4; Sewell 1991). This particular individual was $200 \mathrm{mg}$ total weight. In many of these Year 1 sea cucumbers white testes were ob-

Table 1. Leptosynapta clarki. Laboratory growth. No weight measurements were made at the start of the experiment due to small size. Size-frequency data for this experiment are shown in Fig. 4

\begin{tabular}{|lrrrrr|}
\hline \multirow{2}{*}{ Date } & \multicolumn{4}{l}{ Length (mm) } & \multicolumn{3}{l|}{ Weight $(\mathrm{mg})$} \\
& Mean & SD & Mean & SD & N \\
\hline 24 Jul 1990 & 8.19 & 3.04 & - & - & 245 \\
26 Sep 1990 & 13.37 & 5.13 & 23.0 & 18.6 & 179 \\
10 Dec 1990 & 18.73 & 6.95 & 53.4 & 46.3 & 120 \\
12 Feb 1991 & 19.61 & 6.27 & 50.2 & 31.1 & 98 \\
12 May 1991 & 21.08 & 8.72 & 74.7 & 63.1 & 80 \\
\hline
\end{tabular}

served through the body wall (10 Dec 1990 sample, 65 of 120 were identified as males). Dissections of sea cucumbers in this size range confirmed that L. clarki have active sperm and are reproductively active as males for their first reproductive season

By the end of the first year, the mean size of juveniles was $21.1 \mathrm{~mm}$ length and $74.7 \mathrm{mg}$ weight (Table 1). The largest juvenile was $44 \mathrm{~mm}$ in length (Fig. 2), and $261 \mathrm{mg}$ in weight.

There was considerable variability in growth rate which was partly a result of food availability, but was also related to unintentional damage during measurement. The small size and delicate nature of the body wall made it difficult to remove the sea cucumbers after sieving. Juveniles also autotomize the posterior end which decreases the length and weight. Damage, poor conditions, and loss of some individuals in measurement led to a gradual decline in the number of sea cucumbers. Numbers were reduced from 245 to 80 (Table 1); an overall recovery of $33 \%$.

\section{DISCUSSION}

Two principal methods have been described for the release of embryos from the coelom of internally brooding holothurians: (1) by rupture of the body wall (Leptosynapta clarki: Everingham 1961, present study; Staurothyone inconspicua: Materia et al. 1991; unidentified cucumariid: O'Loughlin 1991) or (2) by escaping through the anus, either by rupturing the rectal wall (Synapta vivipara: Clark 1898; Pachythyone rubra: Chaffee 1982; Lissothuria antillensis: Miller 1985) or via anal pores (Leptosynapta clarki: Brooks 1973). Embryos are also suggested to escape through rectal or abdominal pores in Leptosynapta minuta (Becher 1912, in Ohshima 1916) and Synaptula hydriformis (Turner 1973), and may escape through the anus in Neoamphicyclus lividus (Materia et al, 1991). Opportunistic release of embryos can also occur during autotomy (Brooks 1973, present study), evisceration (Chaffee 1982) or handling (Materia et al. 1991).

Once juvenile Leptosynapta clarki are released from the mother they immediately burrow into the sediment and are visible as a distinct recruitment pulse in the adult habitat. However, while not directly examined in this study there is anecdotal evidence for subsequent dispersal of juveniles from the site of release. This dispersal may occur by rafting, floating, swimming, or incidental dispersal as a result of currents or wave action.

Rafting has been observed in a single Leptosynapta clarki in Mitchell Bay, San Juan Island, Washington, USA, on an Ulva-Monostroma algal mat (Highsmith 1985). During the spring and summer L. clarki at Barge 
Bay are also found within filamentous Enteromorpha spp. mats on the surface of the mudflat. Outgoing tides from Barge Bay include clumps of this alga (pers. obs.) and therefore algal rafting might provide a method for dispersal in both juvenile and adult $L$. clarki (Highsmith 1985).

More passive dispersal might occur if the juveniles can float suspended on the water surface (sensu Highsmith 1985) as noted in juvenile synaptids (Clark 1907). Juveniles of Leptosynapta clarki were often caught in the surface tension in the laboratory and, if present on the mud surface during outgoing tides, could float away from the natal site. The finding of a juvenile $L$. clarki in a collector $10 \mathrm{~cm}$ above the sediment surface in Barge Bay and another in an oblique plankton tow in the mouth of Grappler Inlet (pers. obs.) suggests that there is some potential for dispersal by floating. However, the frequency and importance of floating in this species is as yet undetermined.

Additionally, many apodids are observed to be nocturnal swimmers at restricted times of the year (Leptosynapta inhaerens: Costello 1946; Labidoplax dubia: Hoshiai 1963; Leptosynapta albicans: Glynn 1965). In all cases the sea cucumbers had empty or reduced amounts of sediment in the gut during swimming (Costello 1946, Hoshiai 1963, Glynn 1965). While the velocity of swimming is slow $\left(5\right.$ to $6 \mathrm{~cm} \mathrm{~min}^{-1}$ in juveniles, Costello 1946; ca $1 \mathrm{~m} \mathrm{~min}^{-1}$ in adults, Glynn 1965), if aided by water currents, the sea cucumbers might be able to disperse over a reasonable distance.

Finally, incidental dispersal of juveniles and adults may occur owing to currents or wave action. Engstrom (1980) noted that Chirodota rotifera, if starved or in foul water, would empty the gut of sediment and move actively on the substrate surface. This behaviour made the animals nearly neutrally buoyant and Engstrom (1980) suggested they could be easily transported by tidal currents or mild wave action. Wave action may also sweep juveniles of brooding intertidal species into deeper water (Pseudocucumis africanus: Ohshima 1916; Cucumaria pseudocurata: Rutherford 1973, Martel 1990) or lift burrowing species to the surface during severe storms (e.g. adult Leptosynapta inhaerens: Fish 1925).

Dispersal of either juvenile or adult Leptosynapta clarki may be important in assuring random mating within and between populations. Electrophoretic studies of L. clarki on San Juan Island, Washington, by Hess et al. (1988) found there was enough movement of either individuals or gametes within False Bay to allow random mating and maintain heterozygosity within populations. However, differences in the genetic composition between geographic locations suggests that although gene flow between $L$. clarki populations is probably rare, it does occasionally occur
(Hess et al. 1988). Gene flow could result from the dispersal of juveniles which introduces new males into a population, or as adults. In the latter case, dispersal of brooding female $L$. clarki might introduce large numbers of individuals into a population allowing genetic mixing or colonization of suitable habitat.

While the potential for dispersal in brooding holothurians deserves more attention, the fate of the juveniles once they reach the benthic habitat is virtually unknown. Although recruitment has been studied in holothurians with planktonic larvae (see Ebert 1983, Muscat 1983, Cameron \& Fankboner 1989), there are only a few studies that report finding juvenile apodids (Menker 1970, Rao 1973, Engstrom 1980) and only 1 study of recruitment in a brooding sea cucumber (Cucumaria pseudocurata, Rutherford 1973). The latter study, although only 1 mo in duration, provides the only directly comparable study of recruitment in a brooding sea cucumber.

In brooding species, because the juveniles are usually released over a short period of time and the numbers of recruits are not subject to the vagaries of planktonic transport, we might expect a pronounced increase in the number of juveniles during the period of release. This pattern has been observed in Cucumaria pseudocurata after juveniles crawl from under the mother (Rutherford 1973) and in Leptosynapta clarki after pentactulae release. In the present study there was, however, no dramatic decrease in numbers of juvenile $L$. clarki in the first month as observed in C. pseudocurata (Rutherford 1973). While there must be some juvenile mortality in $L$. clarki, in the present study the juvenile cohort could be followed for approximately 6 mo until it was incorporated into the adult population. This, therefore, provides the first longer-term study of recruitment in a brooding holothurian and in any apodid sea cucumber.

Comparative information on growth rates in brooding sea cucumbers is similarly limited. Growth estimates are available for only 2 species: the external brooder Cucumaria pseudocurata (Rutherford 1973) and the coelomic brooder Chirodota rotifera (Engstrom 1980). There is, however, some qualitative evidence for rapid growth after release in 3 other apodids: Synapta vivipara: Clark 1898, Labidoplax buskii: Nyholm 1951, and Rhabdomolgus ruber Menker 1970.

Once in the sediment, juvenile Leptosynapta clarki grow very rapidly from a length of 1 to $2 \mathrm{~mm}$ to a mean length of $21 \mathrm{~mm}$ in their first year. In $L$. clarki, as in juvenile Cucumaria pseudocurata (Rutherford 1973), this rapid growth occurs during the summer months. The rate of growth observed in L. clarki is comparable to that seen over a shorter period of time in the apodid Chirodota rotifera by Engstrom (1980). Four C. rotifera juveniles collected in sand from Key Biscayne, Florida, 
USA, and maintained in laboratory culture for 3 mo grew from $1.5 \mathrm{~mm}$ to $10 \mathrm{~mm}$ in length before death (Engstrom 1980). As the largest pentactula found in C. rotifera from Jamaica was $3 \mathrm{~mm}$ (Clark 1910), this suggests that Engstrom (1980) cultured recently released juveniles. If this rate of growth had continued these $C$. rotifera would probably have attained a similar size to $L$. clarki in their first year.

By the age of 1 yr, Leptosynapta clarki have already reproduced as males in the early winter (November) December, Sewell \& Chia 1994). Two other apodids show rapid growth and early sexual maturity. The burrowing Labidoplax buskii is sexually mature after 1 yr (Nyholm 1951) and the interstitial Rhabdomolgus ruber has gonads within 4 to 5 mo of settlement (Menker 1970). In the latter species it is, however, unclear whether these individuals reproduce (Menker 1970).

By regular field sampling the population dynamics of Leptosynapta clarki could be followed in Barge Bay from the point of juvenile release. The use of 2 measures of size (length and $\log _{10}$ weight) has allowed the juvenile cohort to be distinguished from adult sea cucumbers in field collections for appoximately 6 mo after release. However, in the absence of distinct year classes in adults and the inability to determine the age of individuals, the rate at which $L$. clarki individuals move through the population from recruitment to death is unknown.

The method developed herein where sea cucumbers could be maintained in the laboratory, with growth rates approximating those in natural conditions, will be a useful tool for future population studies in small burrowing sea cucumbers. For those species in which tagging or marking is inappropriate because of size, a combination of laboratory experiments and field recruitment data may give us a greater insight into the early life history of many smaller sea cucumber species.

Acknowledgements. Thanks to D. Levitan, C. Levitan, T Rawlings, C. Salsbury, and N. Sanders who came on late night excursions to the mudflats to collect sea cucumbers; D. Levitan, J. Havenhand, G. Gibson, H. Clifford, A. Fontaine, J. Holmes, J. Spence and F-S. Chia for comments on the manuscript; and H. Huebscher for translating Menker (1970). Funds to support this research were provided by the Zoology Department, University of Alberta, a Sigurd Tveit Memorial Scholarship from Bamfield Marine Station to the author and an NSERC Grant to F.-S. Chia.

\section{LITERATURE CITED}

Becher, S. (1912). Beobachtungen an Labidoplax buskii (M'Intosh). Z. Wiss. Zool. 101: 290-323

Brooks, E. J (1973). Some aspects of the taxonomy and biology of the genus Leptosynapta (Holothuroidea) in British Columbia. M.Sc. thesis, University of Victoria
Cameron, J. L., Fankboner, P. V. (1989). Reproductive biology of the commercial sea cucumber Parastichopus californicus (Stimpson) (Echinodermata: Holothuroidea). 1I. Observations on the ecology of development, recruitment, and the juvenile life stage. J. exp. mar Biol. Ecol. 127: 43-67

Chaffee, C. (1982). Birth by the viviparous holothuroid Pachythyone rubra (Clark, 1901). In: Lawrence, J. M. (ed.) International Echinoderms Conference, Tampa Bay. A. A. Balkema, Rotterdam, p. 465-466

Clark, H. L. (1898). Synapta vivipara: a contribution to the morphology of echinoderms. Mem. Boston Soc. nat. Hist. 5: $53-88$

Clark, H. L. (1907). The apodous holothurians. Smithson. Contr. Knowl. 35: 231 p., 13 pl.

Clark, H. L. (1910). The development of an apodous holothurian (Chirodotá rotifera). J. exp. Zool. 9: 497-516

Costello, D. P. (1946). The swimming of Leptosynapta. Biol. Bull. 90: $93-96$

Ebert, T. A. (1983). Recruitment in echinoderms. In: Jangoux, M., Lawrence, J. M. (eds.) Echinoderm studies 1. A. A. Balkema, Rotterdam, p. 169-203

Engstrom, N. A. (1980). Development, natural history and interstitial habits of the apodous holothurian Chirodota rotifera (Pourtales, 1851) (Echinodermata: Holothuroidea). Brenesia 17: 85-95

Everingham, J. W. (1961). The intra-ovarian embryology of Leptosynapta clarki. M.Sc. thesis, University of Washington, Seattle

Fish, C. J. (1925). Seasonal distribution of the plankton of the Woods Hole region. Bull. U.S. Bur. Fish. 41: 91-197

Glynn, P. W. (1965). Active movements and other aspects of the biology of Astichopus and Leptosynapta (Holothuroidea). Biol. Bull. 129: 106-127

Hess, H., Bingham, B., Cohen, S., Grosberg, R. K., Jefferson, W., Walters, L. (1988). The scale of genetic differentiation in Leptosynapta clarki (Heding), an infaunal brooding holothuroid. J. exp. mar. Biol. Ecol. 122: 187-194

Highsmith, R. C. (1985). Floating and algal rafting as potential dispersal mechanisms in brooding invertebrates. Mar. Ecol. Prog. Ser. 25: 169-179

Hoshiai, T (1963). Some observations on the swimming of Labidoplax dubia. Bull. mar. biol. Stn Asamushi 11. $167-170$

Martel, A. (1990). Recruitment, post-metamorphic drifting and reproductive output in the herbivorous gastropod Lacuna spp. within kelp canopies and intertidal seaweed communities. Ph.D. thesis, University of Alberta, Edmonton

Materia, C. J., Monagle, J. F., O'Loughlin, P. M. (1991). Seasonal coelomic brooding in southern Australian cucumariids (Echinodermata, Holothurioidea). In: Yanagisawa, T. Yasumasu, I., Oguro, C., Suzuki, N., Motukawa, T. (eds.) Biology of Echinodermata. A. A. Balkema, Rotterdam, p. 301-307

McEuen, F. S. (1987). Phylum Echinodermata: Class Holothuroidea In: Strathmann, M. F. (ed.) Reproduction and development of marine invertebrates of the northern Pacific coast. University of Washington Press, Seattle, p. 574-596

Menker, D. (1970). Lebenszyklus, Jugendentwicklung und Geschlechtsorgane von Rhabdomolgus ruber (Holothuroidea: Apoda). Mar. Biol. 6: 167-186

Miller, J. E. (1985). Viviparity in a psolid holothurian from the tropical western Atlantic. In: Keegan, B. F, O'Connor, B. D. S. (eds.) Echinodermata, Proceedings of the 5th International Echinoderm Conference, Galway. A. A Balkema, Rotterdam, p. 472

Muscat, A. M. (1983). Population dynamics and the effect on the infauna of the deposit-feeding holothurian Parasticho- 
pus parvimensis (Clark). Ph.D. thesis, University of Southern California, Los Angeles

Nyholm, K-G. (1951). The development and larval form of Labidoplax buskii. Zool. Bidr. Upps. 29: 239-254

Ohshima, H. (1916). A new case of brood-caring in holothurians. Annotnes zool. jap. 9: 121-124

O'Loughlin, P. M. (1991). Brooding and fission in shallow water echinoderms of southern Australia. In: Yanagisawa, T., Yasumasu, I., Oguro, C., Suzuki, N., Motukawa, T. (eds.) Biology of Echinodermata. A. A. Balkema, Rotterdam, p. 223-228

Rao, G. C. (1973). Occurrence of some juvenile stages referable to the apodous holothurian Patinapta ooplax (Marenzeller) in the intertidal sands of Andaman Islands. Proc. Indian Acad. Sci. Sect. B. 77: 225-233

Rutherford, J. C. (1973). Reproduction, growth and mortality of the holothurian Cucumaria pseudocurata. Mar. Biol. 22: $167-176$

This article was presented by J. D. Gage (Senior Editorial Advisor), Oban, Scotland
Sewell, M. A. (1991). Protandry in the sea cucumber Leptosynaptasp. Am. Zool. 31: 104A

Sewell, M. A. (1994). Small size, brooding, and protandry in the apodid sea cucumber Leptosynapta clarki. Biol. Bull. 187: $112-123$

Sewell, M. A., Chia, F.-S. (1994). Reproduction of the intraovarian brooding apodid Leptosynapta clarki (Echinodermata: Holothuroidea) in British Columbia. Mar. Biol. (in press)

Smiley, S., McEuen, F. S., Chaffee, C., Krishnan, S. (1991). Echinodermata: Holothuroidea. In: Giese, A. C., Pearse, J. S., Pearse, V. B. (eds.) Reproduction of marine invertebrates, Vol. VI, Echinoderms and lophophorates. Boxwood Press, Pacific Grove, p. 663-750

Turner, R. L. (1973). Release mechanisms for gametes and juveniles of the hermaphroditic coelom-brooder Synaptula hydriformis (Echinodermata: Holothuroidea). Am. Zool. 13: 1337-1338

Manuscript first received: May 3, 1994

Revised version accepted: July 1, 1994 